\title{
Hubungan antara Imunoekspresi Ki-67 dan Risiko Agresivitas Tumor pada Gastrointestinal Stromal Tumor
}

\author{
Herry Yulianti, Bethy S. Hernowo \\ Departemen Patologi Anatomi Fakultas Kedokteran Universitas Padjadjaran \\ Rumah Sakit Dr. Hasan Sadikin Bandung
}

\begin{abstract}
Abstrak
Gastrointestinal stromal tumor (GIST) merupakan tumor mesenkimal yang paling sering terjadi pada traktus gastrointestinal dan berasal dari intestinalcellsofCajalyangterdapatpadalapisan muskularistraktusgastrointestinal yang berfungsi sebagai pacemaker cell dalam mengatur motilitas intestinal. Diperkirakan insidensi GIST 3-5\% dari seluruh soft tissue sarcoma. Gastrointestinal stromal tumor dapat terjadi sepanjang traktus gastrointestinal, terbanyak pada usia pertengahan dan lebih tua, dengan usia rata-rata 50-60 tahun. Secara histologi, terdapat tiga kategori morfologi GIST, yaitu spindle cell, epitheloid, dan mixed type. Marker spesifik GIST adalah cluster of differentiation (CD117) yang mempunyai sensitivitas baik dan imunoreaktif pada 95\% GIST. Ekspresi Ki-67 berhubungan dengan aktivitas proliferasi dan dapat dideteksi pada fase G1, S, G2, dan M dari siklus sel, kecuali pada fase G0. Tujuan penelitian ini adalah mengetahui hubungan risiko agresivitas dengan aktivitas proliferasi yang diukur dengan Ki-67 pada tumor yang telah dikonfirmasi sebagai GIST dengan CD117. Penelitian ini merupakan penelitian analitik potong lintang terhadap 29 kasus GIST dari Departemen Patologi Anatomi Rumah Sakit Dr. Hasan Sadikin/Fakultas Kedokteran Universitas Padjadjaran, Rumah Sakit Santo Borromeus, Rumah Sakit Immanuel, dan Rumah Sakit Santosa Bandung pada tahun 2007-2012. Potongan blok parafin dari 55 kasus GIST diwarnai dengan hematoksilin eosin untuk evaluasi histologi dan evaluasi imunohistokimia menggunakan monoclonal CD117 antibody untuk konfirmasi diagnosis GIST. Terdapat 29 kasus positif dengan CD117, kemudian diwarnai dengan monoclonal Ki-67 antibody. Sel yang dikategorikan positif CD117 memperlihatkan partikel coklat di dalam sitoplasma dan imunoekspresi Ki-67 dinilai dengan warna coklat pada inti sel tumor. Hasil penelitian menunjukkan hubungan bermakna antara risiko agresivitas tumor dan imunoekspresi Ki-67 ( $<<0,001)$. Simpulan, semakin tinggi nilai ekspresi Ki-67 semakin tinggi skor risiko agresivitas sehingga pada GIST, pemeriksaan imunohistokimia Ki-67 dapat membantu menentukan apakah pasien akan mempunyai prognosis yang buruk. [MKB. 2015;47(4):231-6]
\end{abstract}

Kata kunci: CD117, gastrointestinal stromal tumor, Ki-67

\section{Correlation between Ki-67 Immunoexpression and the Tumor Aggressivity Risk in Gastrointestinal Stromal Tumor}

\section{Abstract}

Gastrointestinal stromal tumor (GIST) is the most common mesenchymal tumor of the gastrointestinal tract, and arises from intestinal cells of Cajal localized in the muscular layer of the digestive tract, which functions as pacemaker cells in regulating intestinal motility. The incidence of GIST is about 3-5\% of all soft tissue sarcomas. Gastrointestinal stromal tumor can occur along the gastrointestinal tract and predominantly in middle-aged and older persons, with a median age between 50 and 60 years. Histologically, there are three categories of GIST morphology such as spindle cells, epitheloid, and mixed type. A spesific marker of GIST is cluster of differentiation (CD117), which has good sensitivity and immunoreactive in 95\% of GIST. The expression of Ki-67 correlates with proliferative activities and can be detected in G1, S, G2, and M phases of cell cycle but not in G0 phase. The aim of this study was to assessthe correlation between the risk of aggressive behaviors and proliferative activities as measured by Ki-67 in tumors confirmed as GIST by CD117. The method of this study was cross-sectional, performed on 29 cases of GIST from the Department of Pathology Anatomy Dr. Hasan Sadikin General Hospital/ Faculty of Medicine Universitas Padjadjaran, Santo Borromeus Hospital, Immanuel Hospital, and Santosa Hospital between 2007-2012. A section from paraffin embedded tissue of 55 cases of GIST was stained with hematoxylin eosin for histological and immunohistochemical evaluations using monoclonal antibody CD117 to confirm the diagnosis of GIST. There were 29 positive cases for CD117. Further staining was performed using monoclonal antibody Ki-67. The categorized positive cells of immunoexpression of CD117 showed brown particles inside cytoplasma and the immunoexpression of Ki-67 was assessed by identification of nuclear brown staining of neoplastic cells. The result showed that there were significant correlations between the risk of tumor aggressive behaviors and immunoexpression of Ki-67 ( $\mathrm{p}<0.001)$. In conclusion, as the immunoexpression of Ki-67 value increases, the aggressivity risk score becomes higher. Therefore, in GIST, the Ki-67 immunohistochemical analysis may help to decide which patients will have the worst prognosis. [MKB. 2015;47(4):231-6]

Key words: CD117, gastrointestinal stromal tumor, Ki-67

Korespondensi: Herry Yulianti, dr., Sp.PA, Departemen Patologi Anatomi Fakultas Kedokteran Universitas Padjadjaran/ Rumah Sakit Dr. Hasan Sadikin Bandung, Jalan Pasteur No 38 Bandung, mobile 0811223103, e-mail herryyulianti@yahoo.com 


\section{Pendahuluan}

Gastrointestinal stromal tumor atau GIST adalah tumor mesenkimal yang paling sering pada traktus gastrointestinal $(80 \%)$ dan juga berasal dari sel Cajal pada intestinal yang berfungsi sebagai pacemaker cell yang mengatur motilitas intestinal. ${ }^{1-6}$ Gastrointestinal stromal tumor/GIST merupakan tumor yang jarang terjadi $(10-20$ orang per 1 juta penduduk), di Amerika lebih dari 5.000 kasus baru didiagnosis setiap tahun, dan diperkirakan 3-5\% dari seluruh soft tissue sarcoma. Gastrointestinal stromal tumor dapat terjadi di sepanjang traktus gastrointestinal dan umumnya terbanyak pada lambung $(60-70 \%)$, usus kecil (20-25\%), kolorektum (5\%), dan esofagus $(<5 \%)^{2,4-9}$ Gejala klinis bergantung pada lokasi tumor dan hampir $20 \%$ tanpa gejala. ${ }^{2}$ Gastrointestinal stromal tumor diklasifikasikan sebagai leiomioma/leiomiosarkoma. Terdapat 3 (tiga) kategori morfologi GIST, yaitu spindle cell (70-80\%), epitheloid (20-30\%), dan mixed type $(10 \%)^{3,5,9-13}$

Pengobatan GIST adalah dengan operasi dan pengobatan imatinib yang merupakan inhibitor reseptor tirosin kinase. Sebelum menggunakan imatinib, angka harapan hidup 5 tahun rata-rata pasien dengan operasi adalah 66 bulan dan 9-12 bulan pada pasien yang tidak dilakukan operasi. ${ }^{2}$ Angka harapan hidup 5 tahun 49\% pada lakilaki dan $74 \%$ pada wanita. ${ }^{2,7}$ Hampir $50 \%$ pasien mengalami rekurensi setelah reseksi komplet. ${ }^{2}$ Prognosis GIST bergantung pada indeks mitosis, ukuran tumor, kedalaman invasi, dan juga ada tidaknya metastasis. Tumor dengan ukuran $>10$ $\mathrm{cm}$ atau mitosis $>5 / 50$ high power field (HPF) mempunyai prognosis yang buruk. ${ }^{2,7}$

Cluster of differentiation (CD117/c-KIT) adalah inhibitor tyrosin kinase yang terdapat pada hampir 95\% GIST dan juga merupakan transmembrane protein yang dapat merangsang proliferasi sel serta menghambat apoptosis. ${ }^{2,6}$ Selain itu, GIST juga imunoreaktif untuk CD34 $(30-70 \%)$, S-100 protein $(10 \%)$, dan desmin $(<5 \%))^{1,2}$

Ki-67 merupakan protein non-histon yang berlokasi pada inti dan memiliki masa hidup yang pendek. Masa hidup protein Ki-67 diperkirakan 60-90 menit dan diketahui berhubungan dengan proliferasi sel. Banyak penelitian mengonfirmasi bahwa ekspresi Ki-67 berhubungan erat dengan proliferasi sel. ${ }^{14}$ Ki-67 berhubungan dengan proliferasi antigen inti terekspresi pada seluruh siklus sel khususnya fase G1, S, G2 dan M, kecuali pada fase $\mathrm{G} 0 .^{15-17}$ Gen Ki-67 terdapat pada lengan panjang kromosom 10 manusia (10q25) yang dapat dideteksi pada sel yang mengalami proliferasi baik pada jaringan beku ataupun jaringan pada blok parafin, sedangkan antibodi MIB-1 adalah monoklonal antibodi yang dapat mengenal epitop antigen dari Ki-67. ${ }^{15,16,18}$

Gastrointestinal stromal tumor merupakan tumor mesenkimal yang paling sering terjadi pada traktus gastrointestinal dengan insidensi 3-5\% dari seluruh soft tissue sarcoma. Marker spesifik GIST adalah cluster of differentiation (CD117) yang mempunyai sensitivitas baik dan imunoreaktif pada 95\% GIST. Ekspresi Ki67 berhubungan dengan aktivitas proliferasi. Penelitian ini bertujuan mengetahui hubungan risiko agresivitas dengan aktivitas proliferasi yang diukur dengan Ki-67 pada tumor yang telah dikonfirmasi sebagai GIST dengan CD117.

\section{Metode}

Metode penelitian ini adalah potong lintang terhadap 54 kasus GIST yang terpilih dari pemeriksaan hematoksilin-eosin (HE) yang didiagnosis sebagai GIST yang berasal dari Departemen Patologi Anatomi Rumah Sakit Dr. Hasan Sadikin/Fakultas Kedokteran Universitas Padjadjaran Bandung, Rumah Sakit Santosa, Rumah Sakit Santo Boromeus, dan Rumah Sakit Immanuel Bandung, periode tahun 2007-2012.

Dilakukan pengumpulan blok parafin dari 54 kasus GIST dan dilakukan pewarnaan dengan HE, imunohistokimia CD117 dengan rabbit monoclonal antibody CD117 (Biocare), dan Ki67 dengan rabbit monoclonal antibody MIB1 (Biocare). Ekspresi CD117 dinyatakan positif berdasarkan warna coklat dalam sitoplasma, dan dikategorikan negatif bila jumlah sel positif $<5 \%$, positif bila jumlah sel positif $>5 \%$. Kategori positif (+) bila tampak partikel coklat pucat dalam sitoplasma, positif $(++)$ apabila tampak partikel coklat sedang, dan positif $(+++)$ bila tampak partikel coklat tua. Perhitungan sel yang imunoreaktif dilakukan di bawah mikroskop cahaya dengan pembesaran 400x. Sediaan yang dinyatakan positif CD117, selanjutnya dilakukan pewarnaan imunohistokimia Ki-67 dengan rabbit monoclonal antibody MIB1. Ekspresi Ki-67 dinyatakan positif bila tampak warna coklat pada inti sel dan dihitung sel rata-rata yang terwarnai dalam 500 sel dengan pembesaran 400x.

Blok parafin yang telah dikumpulkan lalu dipotong memakai mikrotom dengan ketebalan $4 \mu \mathrm{m}$, kemudian diletakkan pada object glass yang sudah dilakukan coating dan dilakukan pewarnaan imunohistokimia mempergunakan 
Herry Yulianti: Hubungan antara Imunoekspresi Ki-67 dan Risiko Agresivitas Tumor pada Gastrointestinal Stromal Tumor

Tabel 1 Proposed Approach for Defining Risk of Aggressive Behavior in GIST by Fletcher

\begin{tabular}{|c|c|c|}
\hline Risiko & Ukuran Tumor $(\mathrm{cm})$ & Mitotic Count (HPF) \\
\hline Sangat Rendah & $<2$ & $<5 / 50$ \\
\hline Rendah & $2-5$ & $<5 / 50$ \\
\hline \multirow[t]{2}{*}{ Intermediat } & $<5$ & $6-10 / 50$ \\
\hline & $5-10$ & $<5 / 50$ \\
\hline \multirow[t]{3}{*}{ Sangat tinggi } & $>5$ & $>5 / 50$ \\
\hline & $>10$ & any mitotic rate \\
\hline & any size & $>10 / 50$ \\
\hline
\end{tabular}

Keterangan: HPF=high power field

metode avidin-biotin. Dilakukan deparafinisasi dengan xylol selama 3x5 menit, rehidrasi dengan etanol selama $3 \times 5$ menit, kemudian dengan alkohol 90\%, 80\%, 70\%, dan diinkubasi dengan hydrogen peroxidase 3\% selama masing-masing 5 menit. Bilas dengan akuades, lakukan antigen unmasking retrieval dengan bufer sitrat yang mendidih selama $2 \times 5$ menit. Dinginkan dalam suhu ruangan selama 15 menit. Inkubasi dengan $\mathrm{H}_{2} \mathrm{O}_{2} \quad 0,3 \%$ dalam metanol selama 10 menit, Bilas dengan phosphat buffered saline (PBS). Teteskan blocking serum 1,5\%, inkubasi selama 5-10 menit. Teteskan antibodi primer (CD117/ MIB1) dengan pengenceran 1:150, inkubasi selama 60 menit, kemudian dibilas dengan PBS selama 3x5 menit. Teteskan antibodi sekunder (Biocare Medical) dan juga diinkubasi selama

\section{Tabel 2 Karakteristik Pasien}

\begin{tabular}{lc}
\hline Karakteristik & n \\
\hline Usia & 17 \\
$\quad$ Laki-laki & 12 \\
$\quad$ Perempuan & 55 \\
Rata-rata & \\
Lokasi & 7 \\
$\quad$ Gaster & 1 \\
$\quad$ Duodenum & 7 \\
$\quad$ Jejunum & 4 \\
$\quad$ Kolon & 5 \\
$\quad$ Rektum & 5 \\
Lain-lain & \\
Tipe histopatologi GIST & \\
$\quad$ Spindle cell type & 25 \\
Epitheloid cell type & 4 \\
Mixed type & 0 \\
\hline
\end{tabular}

10 menit selanjutnya teteskan chromogen, lalu inkubasi selama 5-10 menit. Setelah dibilas dengan air mengalir selama 5 menit, dilakukan counterstain dengan mayer hematoxylin selama 2 menit, kemudian dicuci dengan air mengalir. Setelah dilakukan dehidrasi dengan alkohol 70\%, 80\%, 90\%, dan etanol selama 3 menit, kemudian masukkan ke dalam xylol dan terahir dilakukan mounting.

\section{Hasil}

Selama periode tahun 2007-2012 di Bagian Patologi Anatomi Rumah Sakit Dr. Hasan Sadikin Bandung, Rumah Sakit Santo Borromeus, Rumah Sakit Immanuel, dan Rumah Sakit Santosa Bandung terkumpul 54 kasus yang didiagnosis sebagai GIST. Terdapat 29 kasus yang memenuhi kriteria inklusi dan CD117 positif. Dari hasil pemeriksaan dengan pewarnaan $\mathrm{HE}$ terdapat spindle cell type sebanyak 24 kasus, epitheloid

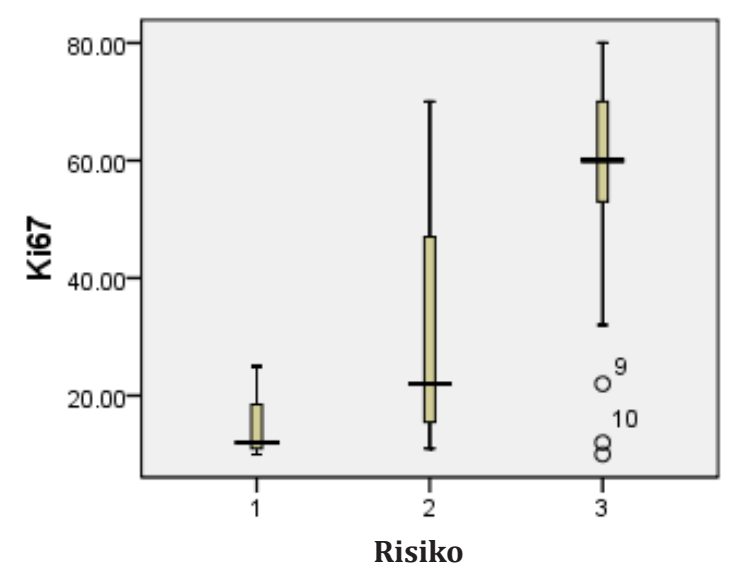

Gambar 1 Box Plot Nilai Ekspresi Ki-67 Menurut Skor Risiko Agresivitas 
Herry Yulianti: Hubungan antara Imunoekspresi Ki-67 dan Risiko Agresivitas Tumor pada Gastrointestinal Stromal Tumor

Tabel 3 Tabulasi Silang GIST Menurut Imunoekspresi KI-67 dan Risiko Agresivitas Tumor

\begin{tabular}{lccc}
\hline \multirow{2}{*}{$\begin{array}{c}\text { Imunoekspresi } \\
\text { Ki-67 }\end{array}$} & Risiko Rendah & Risiko Intermediat & Risiko Tinggi \\
\cline { 2 - 4 } & 3 & 3 & 3 \\
$10-25$ & 0 & 0 & 12 \\
$26-50$ & 0 & 1 & 7 \\
$>50$ & & & \\
\hline
\end{tabular}

type sebanyak 4 kasus, dan tidak ada mixed type.

Analisis statistik mempergunakan statisik korelasi Sommer's d dengan memandang risiko agresivitas tumor sebagai variabel dependen, melalui crosstabs dalam perangkat lunak SPSS 16, diperoleh nilai korelasi Sommer's d 0,519 $(\mathrm{p}=0,001)$. Terdapat hubungan yang erat $(0,519)$ dan sangat signifikan $(\mathrm{p}=0,001)$ antara risiko agresivitas tumor dan imunoekspresi Ki-67.

Semakin tinggi nilai ekspresi KI-67 semakin banyak kasus yang mempunyai skor risiko agresivitas tinggi (Tabel 3). Terdapat 17 kasus dengan nilai ekspresi Ki-67 di atas 50 dan agresivitas tinggi, sedangkan kasus dengan nilai imunoekspresi Ki-67 kurang dari 50, skor risiko agresivitasnya antara rendah dan intermediat.

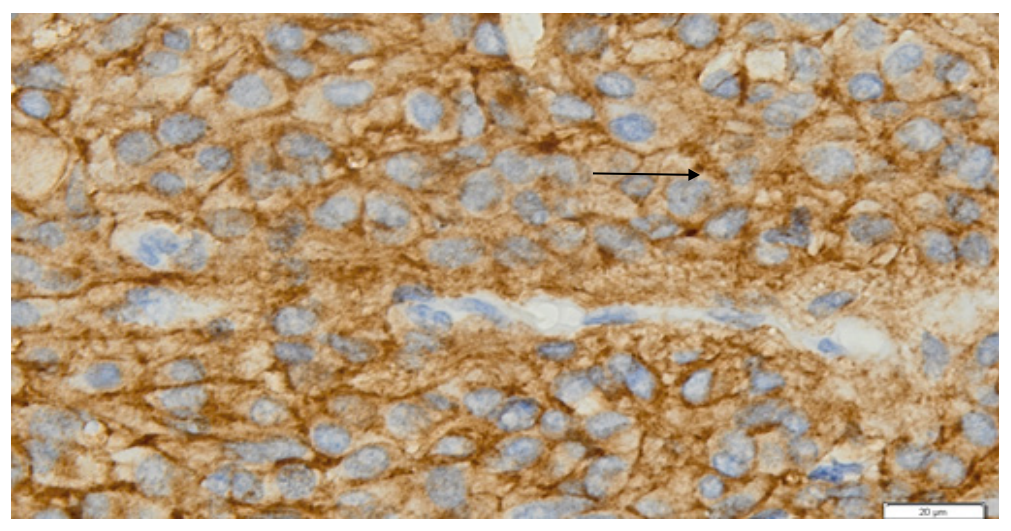

Gambar 2 Imunoekspresi CD117 Positif pada GIST Tipe Epiteloid. Pembesaran 400x. Anak Panah Menunjukkan Partikel Warna Coklat pada Sitoplasma Sel Tumor yang Imunoreaktif

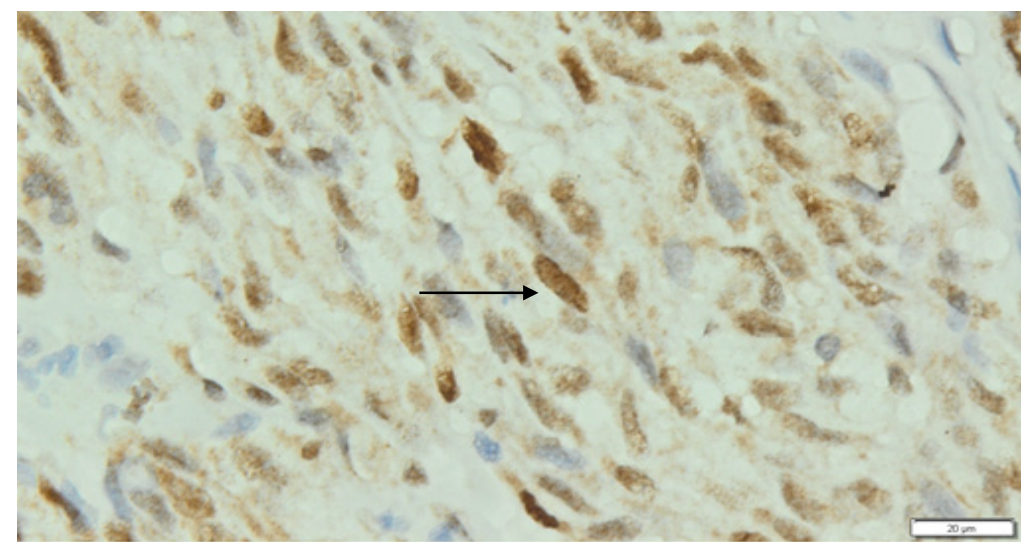

Gambar 3 Imunoekspresi Ki-67 Positif pada GIST Tipe Spindle Cell. Pembesaran 400x. Anak Panah Menunjukkan Partikel Warna Coklat pada Inti Sel Tumor yang Imunoreaktif 


\section{Pembahasan}

Gastrointestinal stromal tumor/GIST merupakan tumor mesenkimal yang paling sering pada traktus gastrointestinal (80\%) dan berasal dari sel Cajal pada intestinal yang berfungsi sebagai pacemakercellyang mengatur motilitas intestinal. Gastrointestinal stromal tumor (GIST) baik jinak maupun ganas pada umumnya memperlihatkan kehilangan pada kromosom 14 dan 22. Proporsi GIST pada umumnya ganas dan memperlihatkan mutasi gen c-kit pada juxtamembrane domain (exon 11). Secara imunohistokimia GIST positif untuk KIT tyrosine kinase receptor yang terlihat pada interstitial cell of Cajal yang dapat mengatur aktivitas motor autonom. ${ }^{6}$

Usia rata-rata penderita adalah 55 tahun, rentang usia 30-89 tahun, sama dengan yang dilaporkan oleh Neves dkk. ${ }^{2}$ yaitu 56 tahun. Lokasi terbanyak pada gaster dan jejunum 7 kasus masing-masing (24\%) dari seluruh kasus, sedangkan paling sedikit pada duodenum hanya 1 kasus (3\%). Presentasi lokasi pada gaster terlihat lebih kecil daripada penelitian Hamilton dan Aaltonen ${ }^{7}$ serta Neto dkk. ${ }^{19}$ yang mencapai 60-70\% dan 40\%. Tipe histopatologi terbanyak adalah spindle cell pada 25 kasus (86\%), tipe epitheloid sebanyak 4 kasus (14\%), dan tidak ada tipe mixed, sedangkan pada penelitian Neto dkk. ${ }^{19}$ terdapat spindle cell (58\%), epitheloid (27\%), dan mixed type (15\%).

Untuk menentukan gradasi GIST secara histopatologi mengikuti sistem yang digunakan untuk soft tissue tumor berdasarkan aktivitas mitosis sebagai kriteria umum. Mitosis $>10$ per $10 \mathrm{HPF}$ dianggap sebagai high grade dan mitosis >1-5 per 10 HPF dianggap sebagai low grade. ${ }^{6}$ Dengan menggunakan kriteria tersebut untuk memisahkan antara GIST jinak dan ganas belum dapat dicapai. Bagaimanapun clinical behavior GIST bergantung pada ukuran tumor dan jumlah mitosis. ${ }^{18}$ Oleh karena itu, Fletcher pada Boni dkk. ${ }^{6}$ membagi GIST ke dalam kelas risiko yang berbeda (Tabel 2). Pada penelitian ini didapatkan GIST dengan risiko rendah pada 3 kasus, risiko intermediat sebanyak 4 kasus, dan risiko tinggi sebanyak 22 kasus.

Setelah dilakukan analisis statistik dengan memakai statisik korelasi Somers'd diperoleh nilai korelasi Sommer's d 0,519 ( $p=0,001)$. Terdapat hubungan yang erat $(0,519)$ dan sangat signifikan $(p=0,001)$ antara risiko agresivitas tumor dan imunoekspresi Ki-67.

Simpulan, semakin tinggi nilai ekspresi Ki67 maka semakin tinggi skor risiko agresivitas sehingga pada Gastrointestinal stromal tumor
(GIST), imunohistokimia Ki-67 dapat menolong menentukan apakah pasien akan mempunyai prognosis yang buruk.

\section{Daftar Pustaka}

1. Rosai J. Stomach. Dalam: Houston M, penyunting. Rosai and Ackerman's surgical pathology. Edisi ke-10. Edinburgh: Mosby; 2011. hlm. 615-49.

2. Neves LR, Oshima CT, Artigiani-Neto R, Yanaguibashi G, Lourenco LG, Forones NM. Ki67 and p53 in gastrointestinal stromal tumors-GIST. Arq Gastroenterol. 2009;46(2):116-20.

3. Dogusoy BG. Gastrointestinal stromal tumors: a multicenter study of 1160 Turkish cases. Turk J Gastroenterol. 2012;23(3):203-11.

4. Fulop E, Marcu S, Milutin D, Borda A. Gastrointestinal stromal tumors: review on morphology, diagnosis and management. Rom J Morphol Embryol. 2009;50(3):319-26.

5. Miettinen M, Lasota J. Gastrointestinal stromal tumors: review on morphology, molecular pathology, prognosis, and differential diagnosis. Arch Pathol Lab Med. 2006;130(10):1466-78.

6. Boni L, Benevento A, Dionigi G, Rovera F, Dionigi R. Surgical resection for gastrointestinal stromal tumors (GIST): experience on 25 patients. World J Surg Oncol. 2005;3:78.

7. Hamilton SR, Aaltonen LA. Tumor of the stomach. Dalam: Hamilton SR, penyunting. World Health Organization classification of tumours. Pathology and genetics of tumor of the digestive system. Lyon: IARC Press. 2010. hlm. 62-3.

8. Sui XL, Wang H, Sun XW. Expression of DOG1, CD117 and PDGFRA in gastrointestinal stromal tumor and correlations with clinicopathology. Asian Pac J Cancer Prev. 2012;13(4):1389-93.

9. Tamiolakis DJ, Venizelos ID, Cheva AD, Lambropoulou MC, Nikolaidou SA, Jivannakis TE, dkk. Fine needle aspiration cytology diagnosis of gastrointestinal stromal tumors utilizing scanning electron microscopy. Medicina. 2005;41(2):117-22.

10. Yang HL, Chang SC, Lan YT, Wang HS, Yang SH, Jiang JK, dkk. The clinicopathologic features and outcome of patients with gastrointestinal stromal tumors in colorectal region. J Soc Colon Rectal Surgeon. 2011;22:115-1.

11. Pauser U, Gunne S, Kloppel G, Merz H, 
Feller C. P53 expression is significantly correlated with high risk of malignancy and epithelioid differentiation in GISTs. An immunohistochemical study of 104 cases. BMC Cancer. 2008;8:204.

12. Lasota J, Corless CL, Heinrich MC, DebiecRychter M, Sciot R, Wardelmann E, dkk. Clinicopathologic profile of gastrointestinal stromal tumor (GISTs) with primary KIT exon 13 or exon 17 mutations: a multicenter study on 54 cases. Mod Pathol. 2008;21(4):476-84.

13. Chan KH, Chan CW, Chow WH, Kwan WK, Kong CK, Mak KF, dkk. Gastrointestinal stromal tumors in a cohort of Chinese patients in Hong Kong. World J Gastroenterol. 2006;12(14):2223-8.

14. Lin MX, Wen ZF, Feng ZY, He D. Expression and significance of Bmi-1 and Ki67 in colorectal carcinoma tissues. Ai Zheng. 2008;27(12):1321-6.

15. Nabi U, Nagi AH, Sami W. Ki-67 proliferating index and histological grade, type and stage of colorectal carcinoma. J Ayub Med Coll Abbottabad. 2008;20(4):44-8.

16. Salminen E, Palmu S, Vahlberg T, Roberts PJ, Soderstrom KO. Increased proliferation activity measured by immunoreactive Ki67 is associated with survival improvement in rectal/recto sigmoid cancer. World J Gastroenterol. 2005;11(21):3245-9.

17. Lazar D, Taban S, Sporea I, Dema A, Cornianu M, Lazar E, dkk. Ki-67 expression in gastric cancer. Results from a prospective study with long-term follow-up. Rom J Morphol Embryol. 2010;51(4):655-61.

18. Urruticoechea A, Smith IE, Dowsett M. Proliferation marker Ki-67 in early breast cancer. J Clin Oncol. 2005;23(28):7212-20.

19. Neto AR, Logullo AF, Stavale JN, Lourenco LG. Ki-67 expression score correlates to survival rate in gastrointestinal stromal tumors. Acta Cir Bras. 2012;27(5):315-21. 